Biol. Stud. 2020: 14(1); 89-104 • DOI: https://doi.org/10.30970/sbi.1401.606

www.http://publications.Inu.edu.ua/journals/index.php/biology

\title{
5
}

UDC: 547.993.02:595.443.8-114.5.008

\section{COMPARATIVE ANALYSIS OF ARANEIDAE VENOMS AND TOXINS: CHEMICAL STRUCTURES AND ELECTROPHYSIOLOGICAL EFFECTS}

\author{
O. M. Klyuchko \\ National Aviation University, 1, Lubomyr Huzar Ave., Kyiv 03058, Ukraine \\ e-mail: kelenaXX@nau.edu.ua
}

Klyuchko O.M. Comparative analysis of Araneidae venoms and toxins: chemical structures and electrophysiological effects. Studia Biologica, 2020: 14(1); 89-104 • DOI: https://doi.org/10.30970/ sbi.1401.606

The aim of present study was to conduct a comparative analysis of electrophysiological characteristics for venoms and toxins of two species (Nephila clavata and Argiope lobate) of spiders (Araneidae) that could be useful for laboratory practice and future investigations. Their venoms and toxins function as antagonists of glutamate receptors, and these substances were used successfully for investigations of membrane structures. The results of the electrophysiological studies of the venoms and toxins are presented for the venom from $N$. clavata and its main active component toxin JSTX-3, and for the venom from $A$. lobata and its three toxins - argiopin AR, argiopinin 1 (ARN-1), argiopinin 2 (ARN-2). The qualitative and quantitative analysis of the correlations between the electrophysiological effects of studied toxins' and chemical structures of their molecules is presented. The problems of complexity of venoms' composition and whether venoms' properties are determined completely by the main active components are discussed. The role of JSTX-3 as a "universal marker of glutamatergic synapses" in different species of fauna are also discussed.

Keywords: venoms of spiders Araneidae, toxins, glutamate receptor antagonists, transmembrane electric current

Nature proposes numerous instruments for scientific investigations. Such instruments, were found in venoms and toxins of some Arthropoda [8, 12, 16, 23, 26, 42, 58, $60,64,65]$. In present study, we addressed the venoms and toxins of two spider (Araneidae) species - Nephila clavata and Argiope lobata (Fig. 1). They are known due to the properties of their venoms as antagonists of glutamate receptors in different biological species. That is why, from the late 1980th, they were successfully used in the electrophysiological experiments, namely for investigation of membrane structures. In previous

() 2020 О. M. Klyuchko; Published by the Ivan Franko National University of Lviv on behalf of Біологічні Студії / Studia Biologica. This is an Open Access article distributed under the terms of the Creative Commons Attribution License (http://www.budapestopenaccessinitiative.org and Creative Commons Attribution 4.0 License), which permits unrestricted reuse, distribution, and reproduction in any medium, provided the original work is properly cited.

ISSN 1996-4536 (print) • ISSN 2311-0783 (on-line) • Біологічні Студії / Studia Biologica • 2020 • Том 14/№1 • C. 89-104 
publications, we have described different Arthropoda venoms and toxins [1, 27-38]. In present publication, we have characterized some electrophysiological properties of $N$. clavata and $A$. lobata products in more details. Here we present the results of experimental studies of glutamate receptors antagonists from Araneidae, namely spider species Nephila clavata and Argiope lobata. These spiders are known as producers of specific venoms and toxins for laboratory investigations. Further, we compared some electrophysiological properties of the venom from $N$. clavata (JSTX-V) with its active component - toxin JSTX-3 and venom from $A$. lobata (AR-V) with its active component - toxin argiopin (AR) with two other toxins from this venom - argiopinin 1 (ARN-1), and argiopinin 2 (ARN-2). We analyzed the results of such comparison in correlation with chemical structures of studied toxins' molecules - JSTX-3, AR (phenol derivatives), ARN-1, ARN-2 (indole derivatives) (Fig. 1). Finally, we have analyzed the relationships between toxins' structures and their electrophysiological effects as a basis for the development of novel methods of quantitative and qualitative investigations. Recently, we have described the development of such methods [27]. In present publication, we presented some experimental results and theoretical conclusions that were put in basis of those methods.

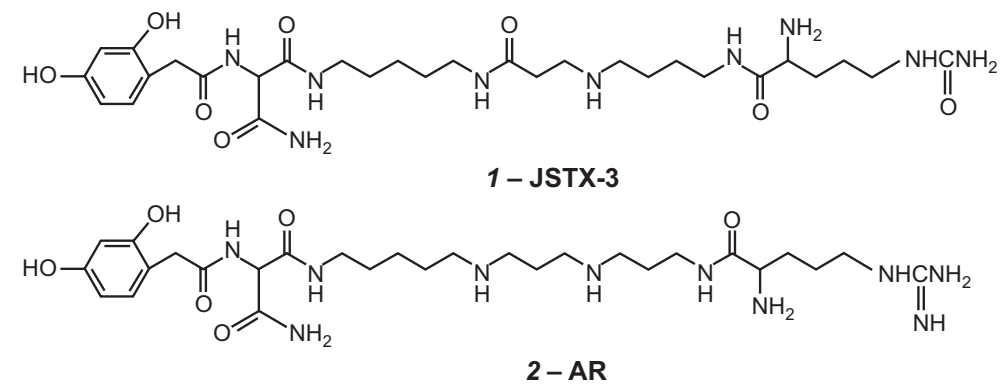<smiles>C[N+](C)(CCCCC(N)C(=O)NCCCCCNC(=O)C(N)CCCNC(=N)N)CCCNC(=O)C(CC(N)=O)NC(=O)Cc1c[nH]c2cccc(O)c12</smiles>
3- ARN-1<smiles>CN(CCCCC(N)C(=O)NCCCCCNC(=O)C(N)CCCNC(N)=O)CCCNC(=O)C(CC(N)=O)NC(=O)Cc1c[nH]c2cccc(O)c12</smiles>
4 - ARN-2

Fig. 1. Chemical structures of studied Araneidae toxins [20, 29]: $1-$ JSTX-3; $2-\operatorname{argiopin} A R ; 3-A R N-1$; 4 - ARN-2. 1 - from Nephila clavata; 2-4 - from Argiope lobata

Pис. 1. Хімічні структури досліджених токсинів аранеїд [20, 29]: 1 - JSTX-3; 2 - аргіопін AR; 3 - ARN-1; 4-ARN-2. 1 - Nephila clavata; 2-4 - Argiope lobata

Different natural venoms and toxins were studied for the neurophysiological investigations, for example the venoms of snakes [7, 10, 16-18, 39, 45, 50], and arthropods $[5,9,43,49,56]$. Numerous results of experimental studies of natural toxins were published in classic monographs by P. G. Kostyuk, O. A. Krishtal, I. S. Magura, I. V. Skok, and others $[40,46,61]$. Later on, these investigations were continued by the representatives of their scientific schools in collaboration with foreign colleagues [1]. The results of study 
of some toxins from Arthropoda (including Araneidae toxins), as well as other similar phenol and indole derivatives, were applied in agriculture [11, 15, 25, 41] and in ecological monitoring of environment [31, 32, 34, 36]. Some of these results were also supported by the patents [30-38]. Because of importance of the results of study of Araneidae venoms and toxins and their applications [1-6, 8, 9, 12-15, 19-29, 42-45, 47-49, 51-54, 56-65], our two previous reviews were devoted to fundamental works of the authors who studied such venoms and toxins [28, 29]. In some of these works, the results of studying of chemical structures of Araneidae toxins, as well as their electrophysiological effects demonstrated blocking different channel-receptors complexes (CRC) $[1,3,4,6,20,21,24,27-38]$.

Investigations of Araneidae toxins are rather important because of the high effectiveness and specificity of these substances. Previously, it was suggested that toxin JSTX might be used as a universal "marker" of glutamate receptors in different representatives of fauna of the Earth. There is a significant similarity of glutamate receptors in different phylogenetically distant organisms: neuromuscular lobster junction, mammals' brain cells and others. Further, it was demonstrated that JSTX-3 cannot be used as "universal marker of glutamatergic synapses" for different species of fauna because of revealing complexity of glutamate CRC molecular structures.

Araneidae venoms and toxins as antagonists of glutamate channel-receptor complex. Numerical results suggested in present article were obtained during the study of the influences of glutamate receptors antagonists from $N$. clavata and $A$. lobata conducted at O.O. Bogomoletz Institute of Physiology, NAS of Ukraine, by a scientific group under the supervision of Prof. O.O. Krishtal, namely by his collaborators Drs. A. Tsyndrenko, N. Kiskin, and O. Klyuchko. Experiments were performed using voltage-clamp technique in a mode of holding potential at rat hippocampal membranes [1, 30-38]. Some of these results are presented in Figs. 2-5.

The venoms from two Araneidae species (Nephila clavata, Argiope lobata) and four toxins from them with known chemical structure were investigated in these our experiments: JSTX-3, AR, ARN-1, ARN-2 (see Fig. 1) [29]. The chemical formula of JSTX-3 molecule consists on the 2,4-dihydroxyphenylacetate-asparagine coupled to the polyamine $[3,24]$. The molecular weight of AR is $646 \mathrm{Da}$, its chemical structure is depicted in Fig. 1. It is a 2,4-dihydroxyphenylacetat-asparagine that is linked through a polyamine with the terminal arginine [6, 20, 21]. According to the results of UV-spectroscopy, all components of the venom AR-V were separated into three types: argiopin, argiopinins and pseudoargiopinins (in Fig. 1, one can see 4 toxins studied in the framework of present work). Thus, argiopin contains phenolacetic acid, argiopinins - dihydroxyindolacetic acid, and pseudoaryhopinins - indolacetic acid. Shorter fragments of JSTX-3 were mentioned in present article - 2,4-dihydroxyphenylacetat-asparparin (DHPhA-Asp) and 2,4-dihydroxyphenylacetic acid (DHPhA). More information about Araneidae toxins chemical structures is in [29].

Among these toxins, JSTX-3 has the simplest structure: its polyamine chain is the shortest and has no branching. The AR molecule has longer polyamine chain attached to it by 2 reactive amino groups. $A R N-1$ and $A R N-2$ have the polyamines with equal lengths to which amino groups are also attached. A distinctive characteristic of ARN-1 is the easily dissociating cationic group that contains the pentavalent nitrogen in the polyamine chain. According to the length of polyamine chain, all studied toxins can be arranged in following sequence:

$$
\text { JSTX-3 <AR }<\text { ARN-1 = ARN-2. }
$$




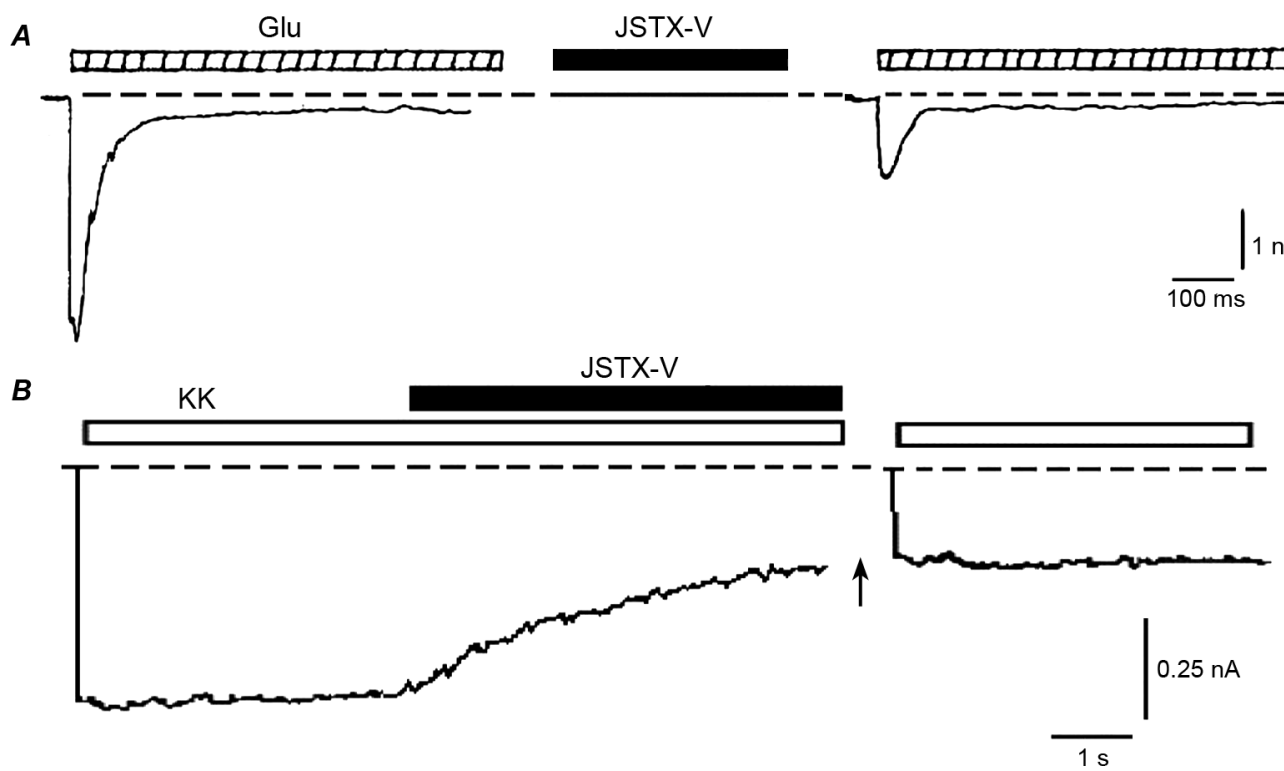

Fig. 2. Characteristics of influence of JSTX-V: the venom decreased irreversibly the amplitudes of glutamateand kainate-activated electrical currents up to approximately $2 / 3$ of their initial values in concentration $2.5 \cdot 10^{-5} \mathrm{units} / \mu \mathrm{L}$. It was not possible to restore the amplitudes of these currents after $6 \mathrm{~min}$ of membrane "washing" in Ringer solution. After the registration of control response to Glu and KK, the membrane was maintained in JSTX-V during $3 \mathrm{~min}$, after this the decrease of amplitudes of chemo- activated currents had happened. $\boldsymbol{A}$ - JSTX-V influence on glutamate-activated electrical current; $\boldsymbol{B}$ JSTX-V influence on KK-activated currents, arrow indicates the moment of start of venom "washing". Concentrations of Glu and $\mathrm{KK}$ were $1 \mathrm{mmol} / \mathrm{L}, \mathrm{V}_{\text {hold }}=-100 \mathrm{mV}$. Records $\boldsymbol{A}, \boldsymbol{B}$ were done at different cells

Рис. 2. Характеристика впливу JSTX-V: отрута необоротно зменшувала амплітуди глутамат- і каїнатактивованих електричних струмів приблизно до 2/3 їхніх початкових значень у концентрації $2,5 \cdot 10^{-5}$ од./мкл. Було неможливо відновити амплітуди цих струмів через 6 хв відмивання мембрани в розчині Рінґера. Після реєстрації контрольної відповіді на Glu та KK мембрану витримували в JSTX-V протягом 3 хв, після чого відбувалося зменшення амплітуд хемоактивованих струмів. $\boldsymbol{A}$ - вплив JSTX-V на глутаматактивований електричний струм; $\boldsymbol{B}$ - вплив JSTX-V на KK-активований струм, стрілка вказує на початок "відмивання" отрути. Концентрації Glu та KK становили 1 ммоль/л, $\mathrm{V}_{\text {hold }}=-100$ мВ. Записи $\boldsymbol{A}$, В були зроблені на різних клітинах

Comparison of properties of integral venoms and toxins. As noted earlier, integral toxins of Arthropoda are heterogeneous mixture of substances that contain their own toxins, enzymes, amino acids and other substances [2, 13, 28, 29]. The main active component of integral venom JSTX-V is the toxin JSTX-3; of integral venom AR-V is the toxin argiopin AR. As it was demonstrated in numerical experiments, the processes of chemo-active currents blocking by venoms and their toxins have a number of common features. They all suppressed to different degree the amplitude of transmembrane chemosensitive electrical currents activated by such agonists as glutamate (Glu), its analogue kainate (KK, activated non-desensitized stationary currents), and quisqualate (QL). In our experiments at O.O. Bogomoletz Institute of Physiology, National Academy of Science of Ukraine, the results that were put in basis of analysis performed in this article were obtained [1, 27, 30-38].

In Figs. 2, 3 the blocking effect of integral venom JSTX-V and its main active component JSTX-3 on chemo-activated currents in rat hippocampal membrane is demonstra- 
ted. In Fig. 4, the blocking activity of integral venom AR-V on chemo-activated currents in neuronal membrane is shown. In Fig. 5, the blocking activity of the toxin argiopin (AR), the main active element from this venom is presented. In our experiments, all antagonists - venoms and toxins - acted in a reversible manner on glutamate receptors in hippocampal membranes, but the rates of their reversible effects were different in all cases (Fig. 6).

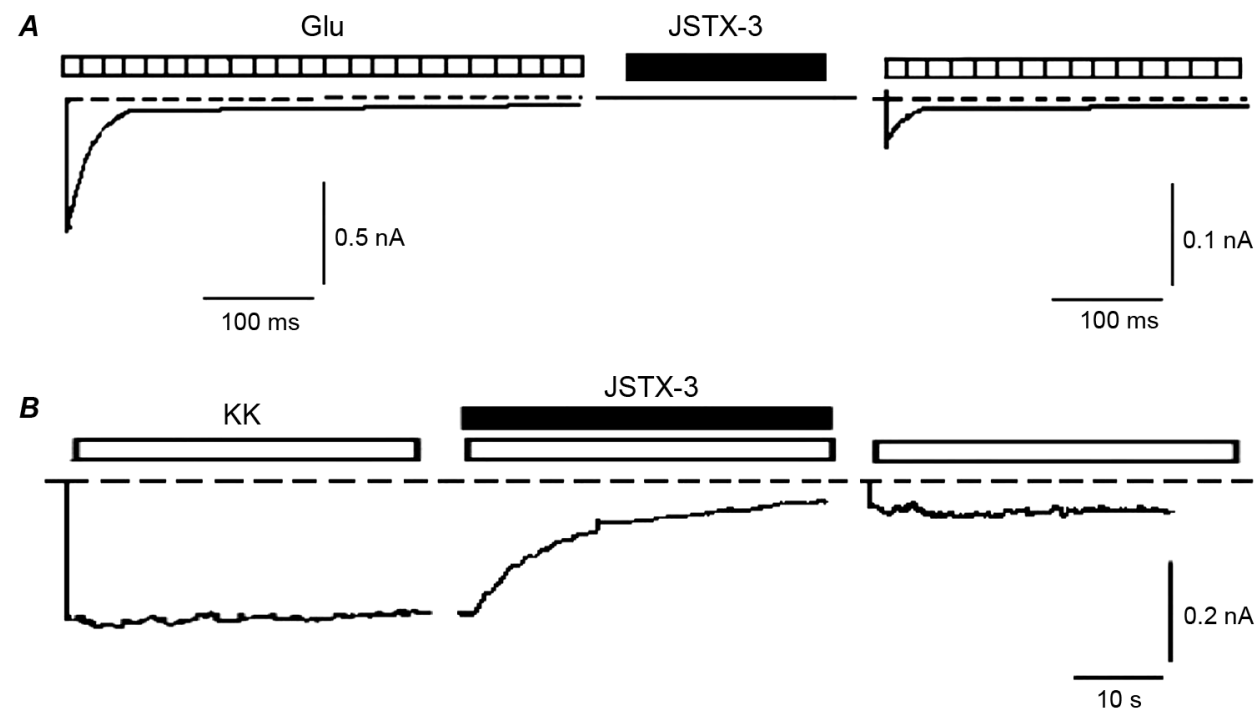

Fig. 3. Blocking of chemo-activated transmembrane electrical currents by toxin JSTX-3: $\boldsymbol{A}$ - glutamate-activated; $\boldsymbol{B}$ - kainat-activated ion currents. a) The scheme of the experiment is the same as at Fig. 1. b) After the receiving of the control response to KK, toxin JSTX-3 was applied by the background of KK-activated current. Concentrations Glu and KK were $1 \mathrm{mmol} / \mathrm{L}$, JSTX-3 was $10^{-4} \mathrm{~mol} / \mathrm{L}, \mathrm{V}_{\text {hold }}=-50 \mathrm{mV}$. Records $\boldsymbol{A}$ and $\boldsymbol{B}$ were done on different neurons

Рис. 3. Блокування хемоактивованих трансмембранних електричних струмів токсином JSTX-3: $\boldsymbol{A}$ глутаматактивовані; $\boldsymbol{B}$ - каїнатактивовані іонні струми. а) Схема експерименту така ж, як на рис. 1. б) Після отримання контрольної відповіді на KK токсин JSTX-3 аплікували на тлі KK-активованого струму. Концентрації Glu i KK становили 1 ммоль/л, JSTX-3 був 10-4 моль /л, $\mathrm{V}_{\text {hold }}=-50 \mathrm{mB}$. Записи $\boldsymbol{A}$ та $\boldsymbol{B}$ були зроблені на різних нейронах

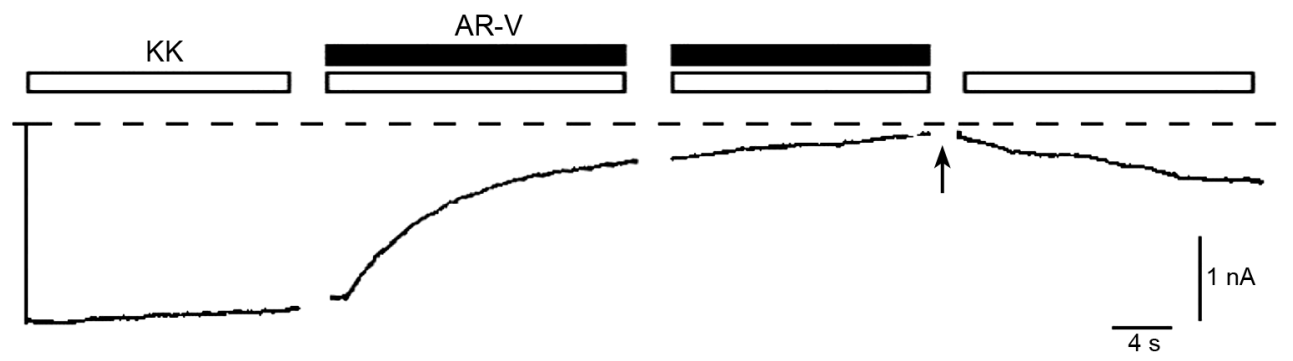

Fig. 4. Peculiarities of action of venom from $A$. lobata (AR-V): open channel blocking, weak reversibility of action (explanation see in text). Concentrations: $\mathrm{KK} 1 \mathrm{mmol} / \mathrm{L}, A R-\mathrm{V} 10^{-4} \mathrm{~g} / \mathrm{ml}, \mathrm{V}_{\text {hold }}=-100 \mathrm{mV}$

Рис. 4. Особливості дії отрути з A. lobata (AR-V): блокування відкритого каналу, слабка зворотність дії (пояснення див. у тексті). Концентрація KK 1 ммоль /л, AR-V 10-4 г/мл, $\mathrm{V}_{\text {hold }}=-100 \mathrm{mB}$ 


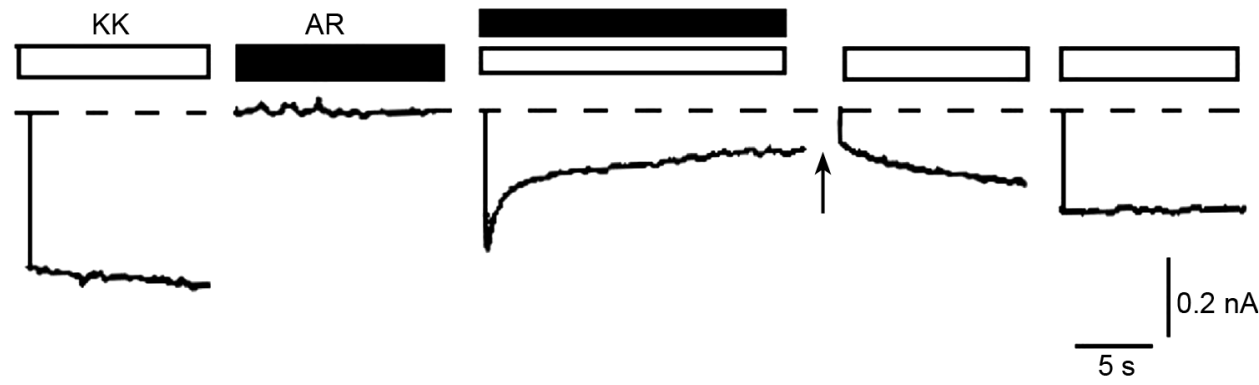

Fig. 5. Argiopin causes blockage of the open state of kainat-activated ion channels. After receiving of control response, the neuron was maintained in AR during $3 \mathrm{~min}$, then on background of AR the KK was added. Concentrations: KK $1 \mathrm{mmol} / \mathrm{L}, \mathrm{AR} 1.6 \cdot 10^{-2} \mathrm{~mol} / \mathrm{L}, \mathrm{V}_{\text {hold }}=-100 \mathrm{mV}$. Toxin removing by "washing" was $15 \mathrm{~s}$

Рис. 5. Аргіопін викликає блокування відкритого стану каїнатактивованих іонних каналів. Після отримання контрольної відповіді нейрон витримували в AR протягом 3 xв, потім на тлі AR додавали KK. Концентрації: KK 1 ммоль/л, AR 1,6·10-2 моль/л, $\mathrm{V}_{\text {hold }}=-100$ мВ. Видалення токсину способом "відмивання" становило 15 с

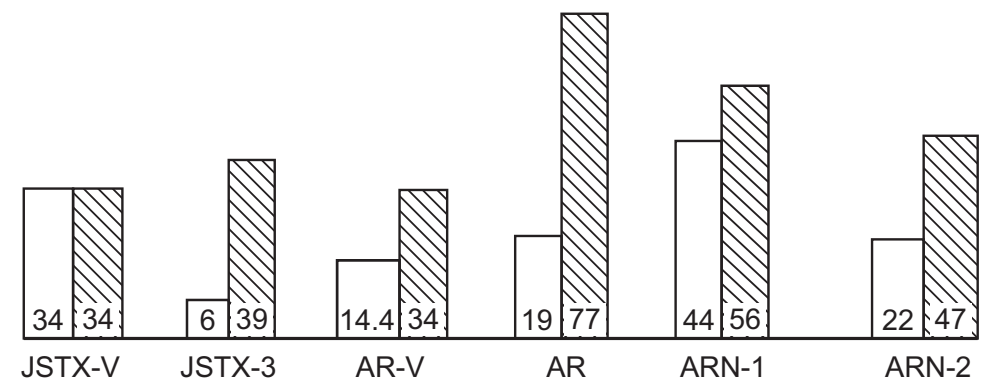

Fig. 6. The degree of blocking of kainat-activated currents by various antagonists (white columns) and the degree of recovery of currents' amplitudes after the antagonists removing in Ringer's solution (shaded columns). The values are given in percent of the amplitude of control response, the value of which was taken for $100 \%$ (top straight dotted line). Diagram was done for 6 different antagonists of glutamate channel-receptor complexes [27]

Рис. 6. Ступінь блокування каїнатактивованих струмів різними антагоністами (білі колонки) і ступінь відновлення амплітуд струмів після видалення антагоністів у розчині Рінґера (заштриховані колонки). Значення наведено у відсотках від амплітуди контрольної відповіді, значення якої прийнято за 100 \% (верхня пряма пунктирна лінія). Діаграму виконано для 6 різних антагоністів глутаматних канало-рецепторних комплексів [27]

In our experiments, both argiopin and AR-V blocked only the opened channel (Figs. 4, 5). The pair JSTX-3 and JSTX-V differed from them in their characteristics. JSTX-V and JSTX-3 acted both on opening and closure of Glu- and KK-activated channels (Figs. 2, 3). Any differences between antagonists were not detected in experiments for studying of potential-dependence of these toxins' actions. The action of all four antagonists to a greater or lesser extent depended on the holding membrane potential: the blocking properties of all of them become worth with membrane depolarization. 
Regarding the differences in the action between the pairs of venom-toxin from N. clavata and venom-toxin AR from A. lobata - they were visible in degrees of current blocking and their recovering during "washing", as well as in numerical values of parameters of blocking and "washing" (Fig. 6).

During the study of kinetics of electrical transmembrane currents blocking at the background of stationary KK-activated ionic currents, it was found that the pairs "venomtoxin" had similar kinetics of blocking (see Table) [32-56]. Thus, the blocking processes of CRC by both JSTX-V and JSTX-3 could be described by one exponent. The same processes of channel-receptor complex (CRC) blocking by AR-V and AR were approximated satisfactorily by two exponents in both cases (see Table) [32-56]. One exponent could also describe the process of AR-V and AR removing by "washing" in Ringer's solution. Qualitatively, general features of the action in "venom-toxin" pairs were reflected in the existence of one constant of the reaction of interaction of JSTX-V and JSTX-3 with $\mathrm{CRC}$ and two constants of the direct reaction of interaction between AR-V and AR. Quantitatively, the rate of interaction of antagonists with CRC can not be compared, since the concentrations of venoms and toxins were measured in different units. No differences were found in the specificity of antagonists' action within the pairs JSTX-V and JSTX-3; or AR-V and AR. In used conditions, they all suppressed the amplitudes of only Glu-, KK-, QL-activating currents. Consequently, in the composition of the venoms there were no antagonists of other receptors, namely GABA and glycine receptors.

Kinetic characteristics of blocking of KK-activated ionic currents [27] Кінетичні характеристики блокування КК-активованих іонних струмів [27]

\begin{tabular}{l|c|c|c|} 
Antagonist & \multicolumn{2}{|c|}{ Constant rate of blocking (direct reaction) } & $\begin{array}{c}\text { Velocity of electrical current } \\
\text { amplitude recovering }\end{array}$ \\
\cline { 2 - 4 } & $\mathrm{K}_{1}$ & $\mathrm{~K}_{2}$ & $\mathrm{v}_{-}$ \\
\hline JSTX-V & $4.4 \cdot 10^{3} \mu \mathrm{L} /($ un.s) & - & 0 \\
\hline JSTX-3 & $2.1 \cdot 10^{3} \mathrm{~L} /(\mathrm{mol} . \mathrm{s})$ & - & $1.3 \cdot 10^{-2} \mathrm{~s}^{-1}$ \\
AR & $1.6 \cdot 10^{3} \mathrm{~L} /(\mathrm{mol} . \mathrm{s})$ & $0.85 \cdot 10^{4} \mathrm{~L} /(\mathrm{mol} . \mathrm{s})$ & $4.2 \cdot 10^{-2} \mathrm{~s}^{-1}$ \\
ARN-1 & $3.3 \cdot 10^{3} \mathrm{~L} /(\mathrm{mol} . \mathrm{s})$ & $1.6 \cdot 10^{4} \mathrm{~L} /(\mathrm{mol} . \mathrm{s})$ & $7.9 \cdot 10^{-2} \mathrm{~s}^{-1}$ \\
ARN-2 & $2.9 \cdot 10^{3} \mathrm{~L} /(\mathrm{mol} . \mathrm{s})$ & $0.59 \cdot 10^{4} \mathrm{~L} /(\mathrm{mol} . \mathrm{s})$ & $3.1 \cdot 10^{-2} \mathrm{~s}^{-1}$
\end{tabular}

A described similarity in characteristics of actions of venoms and toxins (their main active components) allow to conclude that the physiological properties of the venom JSTX-V and AR-V were determined by the toxins JSTX-3 and AR, respectively. However, the contribution of these toxins in overall effect although maximal, but does not exhaust all the properties of the venom. For example, the irreversibility of JSTX-V action (unlike JSTX-3), might be explained by the presence of other fractions in the venom, that are bound with the membrane irreversibly. During binding, such blockers could change irreversibly the properties of glutamate channel-receptor complex (gCRC) by themselves, or they could operate through different, more complex mechanisms. Via binding with the membrane, but not blocking the gCRC by itself, they could increase the stability of the complex gCRC - JSTX-3. Although the probability of second assumption is less, we can not refuse from it absolutely.

The results of our studies of venoms and toxins from $A$. lobata suggest the following mechanism. AR-V is "washed" much worse than AR. AR-V contains a number of fractions 
with toxic activity; AR is only one of them. Such fractions were capable to block KK-activated currents practically irreversibly. After studying of composition of venom AR-V, other active components like argiopinin 1 (ARN-1) and argiopinin 2 (ARN-2) have been isolated from it $[28,29]$. Both these substances blocked KK-activated currents, forming significantly more stable links on the membrane than AR. It was possible to see that argiopinin 1 acts less reversibly than other antagonists. Obviously, the greater degree of irreversibility of AR-V action in comparison with AR is determined by ARN-1 and similar toxins.

The pair JSTX-V and JSTX-3 the largest difference in these characteristics demonstrated. During the action of integral venom the amplitude of KK-activated response fell to a new steady state (34 \% of control response) and no longer recovered. Then the JSTX-3 toxin was able to be removed partially with the recovery of the response amplitude (from $64 \%$ to $39 \%$ of control response). The same tendency but in less degree was observed in AR-V and AR pair. Thus, the degree of AR-V ability for removing is really lower (from $14 \%$ to $32 \%$ of control response) than for AR (from $20 \%$ to $77 \%$ of the control response).

We took into account the complexity of venoms composition. For example, any of the well-purified or synthetic toxins did not activate transmembrane ion currents by itself. If such activation occurred, the analysis showed the presence of glutamate in such poorly purified preparations. This fact makes us doubt in the data of other authors [63] who found that that Arthropoda toxins activate ion currents in the membranes by themselves. As a rule, the rough preparations or integral venoms were used in those experiments.

Other our results might be caused by complex composition of venoms. All venoms and toxins were kept frozen at $-4{ }^{\circ} \mathrm{C}$. During the first $3-4$ months, the properties of those venoms remained unchanged. However, with long-term storage (more than 6-7 months), the properties of integral venoms be changed. For example, JSTX-V began to "wash off" after its removing, the KK-activated responses were partly restored. Similar observation was made by Japanese authors [47, 48, 57]. However, is impossible to answer unambiguously why is that happening. Possibly, venom preparations are less stable than individual toxins due to the mutual influence of venom components. With a prolonged storage, the molecules of irreversibly active substances can be decomposed more quickly. During dissolving, low molecular weight substances interact with the membrane. It is possible to explain that effect better after a more detailed study of Arthropoda venoms' and toxins' properties.

Comparative analysis of properties of different Araneidae toxins in a link with their chemical structures. The influences of all studied toxins on the glutamate receptor were characterized by a number of common features. They all blocked glutamate- (GLU), kainate- (KK), and quisqualate (QL)-activated currents in rat hippocampal membranes to various degrees and were washed differently. They did not act on the excitatory, glycine-, and GABA-activated currents in these neurons. Their blocking action depended on the transmembrane holding potential - it became worth with membrane depolarization. All these substances could block the open channels in gCRC. It is possible to assume that properties of these toxins are due to the fragments of molecules that are common to all toxins: phenolic or indole fragment coupled to asparagine.

Our experiments did not demonstrate any significant differences in the properties of toxins containing phenolic or indole fragments. The only slight difference is that the dissociation of AR derivatives that contained indole groups is slowed down slightly (see the

ISSN 1996-4536 (print) • ISSN 2311-0783 (on-line) • Біологічні Студії / Studia Biologica • 2020 • Том 14/№1 • C. 89-104 
Table). However, the direct constant rates of toxins' interaction with AR derivatives did not differ significantly. Such pattern of properties of toxins, phenol- and indole- derivatives allows to make some conclusions (see below).

First, the mechanism of gCRC block by toxins should be based on the reaction of the interaction of aromatic toxin groups with membrane groups. Second, this reaction have to be common to indole and phenolic groups, so, the membrane should not "differentiate" them. Finally, probably these groups (or linked with asparagine) predetermine the effect of gCRC block and its main features (potential-dependence and others).

Influence of toxins on activated and non-activated receptor. The main difference in the action of toxins is that JSTX-3 interacts with gCRC, regardless of whether it is in the activated state or non-activated (Fig. 3). From other side, the main mechanism of action of AR, ARN-1, ARN-2 is the blocking of GLU- and QL-activated channels in the open state (Fig. 5). Similar results were obtained previously for AR [21, 24]. What is the explanation in difference in the toxins action? The only structural difference between JSTX-3 and other ones is more simple molecular structure of the first one. It is possible that further minor complication of structure of $A$. lobata toxins' molecules (extension of their polyamine chains, adding of amino groups branched from the main chain), increases the selectivity of their interaction with gCRC in such a way that they lose the ability to bind to gCRC in the non-activated conformation. Thus, were simple JSTX-3 molecule is less "legible" and "do not distinguish" the receptor conformations that correspond to the activated and inactivated states. In both cases, JSTX-3 molecule blocks the ion currents almost completely. We would like to carry out similar experiments investigating more simple fragments of JSTX-3 molecule - 2,4-dihydroxyphenylacetat-asparparin (DHPhA-Asp) and 2,4-dihydroxyphenylacetic acid (DHPhA) that can block gCRC [53].

An interesting feature is that the processes of AR and JSTX-3 removing by "washing" in Ringer's solutions (both in the presence and without agonists (GLU, KK)) were similar. According to our preliminary data, the presence of agonists ( $G L U, K K$ ) was necessary for the better "washing" of argiopin and some argyopinins in solutions. The processes of formation and dissociation of toxin-receptor complexes were better for these substances with the activation of gCRC. According to the literature data, another toxin - gCRC antagonist with similar characteristics is known: $\delta$-philanthotoxin [4]. However, a significant difference in structure of its molecule (it has oxyphenol instead of 2,4-DHPhA or 2,4-DHPhA-Asp) and the absence of data on that issue does not allow us to make any conclusions about the relationship of its properties with the structure of its molecule.

According to data of some authors', the necessary condition for AR "washing" is the presence of agonist in washing solutions [48, 24]. This contradicts to the results of our researches. However, that effect is easy to explain taking into account that in those works the roughly purified AR preparations were used. That effect could be caused by the impurities of argiopinins.

It should be noted that the obtained regularities of toxins' properties' correlation with their structure may be changed during the study of newly obtained antagonists with another chemical structures.

Degree of KK-activated currents blockage. None of studied toxins could block KKactivated currents completely, even at high concentrations $\left(10^{-4} \mathrm{~mol} / \mathrm{L}\right)$. JSTX-3 suppressed the amplitudes of KK-activated currents the most effectively - up to $6 \%$ of the initial values. The efficiency of KK-activated currents suppression decreased from left to right in the following sequences of toxins: JSTX-3 > AR > ARN-2 > ARN-1. As one can see, the degree of current suppression by the toxins may depend on the length of their polyamines:

ISSN 1996-4536 (print) • ISSN 2311-0783 (on-line) • Біологічні Студії / Studia Biologica • 2020 • Том 14/№1 • C. 89-104 
the shorter the toxin, the more effectively it closes the ion channel. However, this finding should be supported by additional studies of other analogs with different lengths of polyamine chain.

Irreversibility of toxins' action. For JSTX-3 analogues with different polyamine lengths, it was found that polyamine chain elongation caused the formation of more stable toxin-receptor complex [22, 24]. However, AR demonstrated more revealed reversible action, although its length is only slightly longer than that of JSTX-3. Perhaps, this is due to the fact that two amino groups linked with AR polyamine chain can react easily, and the length of polyamine appeared to be functionally less important? To answer this question, we studied how the toxin structure is related to the rate of "washing" of other A. lobata toxins (see Table, Fig. 6).

We demonstrated that AR was in separate position among the other studied toxins from A. lobata. All other A. lobata toxins were "washed" much worse, regardless of their structures. However, if to study the sequence of analogs separately, it was shown that it was easier to wash the substances with longer polyamine fragment. This was true within the groups of argiopinins 1-5 and pseudoargiopinins 1-3 (see [29]). Our conclusion is opposite to the conclusion of other authors, that was made earlier for JSTX-3 analogues (see above). Thus, for AR and its analogues - the longer is the toxin molecule, the better it is "washed". The exception was ARN-1 (arginopinin 1) whose action is almost irreversible. However, unlike other toxins, its polyamine contains an easily dissociated cationic group with pentavalent nitrogen. This group probably contributes to the formation of more stable toxin-receptor complex.

Kinetic characteristics of toxins' blocking action. Based on the calculations' for the values of toxins' binding constants and constants of toxins' "washing" (see the Table), as well as on the basis of previous data obtained during the study of argiopinins 1-5 and pseudoargiopinins 1-3, the following conclusion was done. With the lengthening of the polyamine chain, the values of the first binding constants of the toxins with $g C R C$ increased, and the constants of toxins "washing" increased too. Otherwise, the longer is the toxin molecule, the faster it binds to the receptor and breaks the links with gCRC more quickly during dissociation. This rule is not true for the molecules having long side chains, namely ARN-4, whose binding constant is higher than expected. Perhaps, this regularity should be transformed as follows: the longer and more branched is the toxin molecule, the faster it binds and breaks the bonds with gCRC.

Relationships between toxins structures and their electrophysiological characteristics as a base for novel methods of quantitative and qualitative analysis. All toxins studied in this work were isolated both from the natural source - venoms, and were synthesized in laboratory conditions. The effect of synthetic analogues was completely identical to the action of natural toxins. This confirms the correctness of the decoded toxins' structures and the identity of the synthetic toxins with the corresponding natural analogs.

We suggest that the relationships between toxins structures and their electrophysiological properties described above can be used for the development of novel methods of qualitative and quantitative analysis [27, 33, 37, 38]. Accordingly, this our suggestion can be defined as following algorithm.

1 - The necessary electrophysiological characteristics have to be registered in experiments. 2 - These data have to be accumulated and ordered in databases. 3 - The relationships between toxins structures and their electrophysiological properties have to be established and revealed (for example, in a graph form). 4 - Unknown chemical

ISSN 1996-4536 (print) • ISSN 2311-0783 (on-line) • Біологічні Студії / Studia Biologica • 2020 • Том 14/№1 • C. 89-104 
substance can be defined on the base of established relationships in comparison with known substances. It is necessary to emphasize that such methods have to be based obviously on good statistics and developed computer basis.

Abovewritten can be illustrated by a simple qualitative graph (Fig. 7) [27]. Axis OXchemical structures (phenol and indol derivatives); their structure complication is from the left to right. Axis OY - qualitative representation of the effects described in this article. In the circles, the numbers 1, 2 mean following regularities: 1 is the decrease of effect with chemical structure complication, and 2 is the increase of effect with chemical structure complication [27, 33, 37, 38].

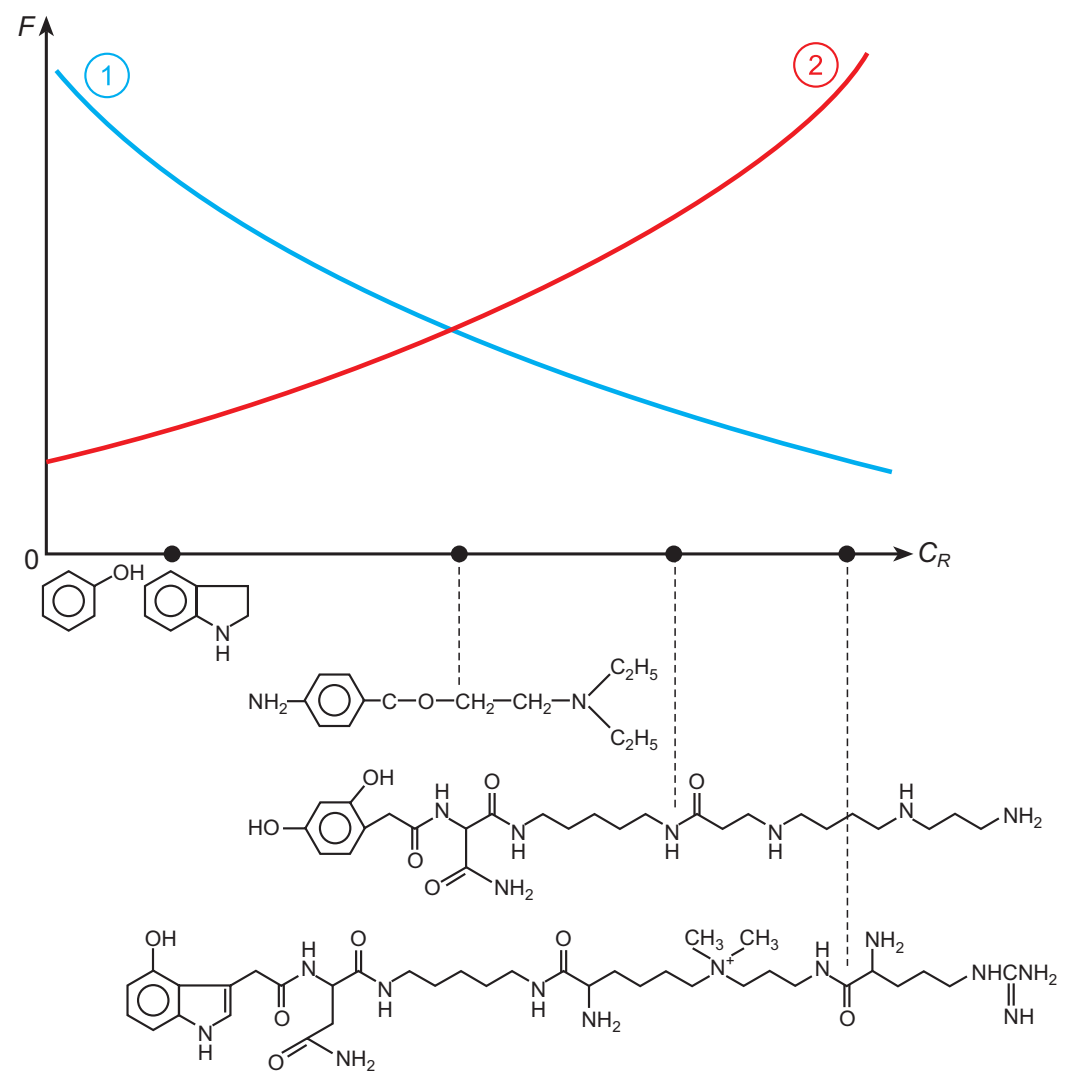

Fig. 7. Qualitative regularities of damaging toxic effect of studied substances [27, 33, 37, 38] (details see in text)

Рис 7. Якісні залежності пошкоджувального токсичного впливу досліджених речовин [27, 33, 37, 38] (пояснення у тексті статті)

\section{CONCLUSIONS}

In present article we have analyzed the results of the studies of some Araneidae substances. The results of investigations of two spider species - Nephila clavata and Argiope lobata are presented. Some electrophysiological characteristics of these venoms and toxins - their main active components - have been observed. The results of electrophysiological properties studies for the pairs: venom from $N$. clavata with toxin JSTX-3, and venom from $A$. lobata with toxins argiopin AR, ARN-1, ARN-2 are presented in parallel. A described similarity in characteristics of actions of venoms and 
toxins (their main active components) allows concluding that the physiological properties of the venom JSTX-V and AR-V are determined by the toxins JSTX-3 and AR, respectively. However, although the contribution of these toxins in overall effect is significant, it does not cover all properties of the venom.

The similarity in blocking characteristics between each venoms and corresponding toxins is presented. In our comparative analysis of correlations between the electrophysiological effects of studied toxins and their chemical structures, following effects of these interactions were studied: 1 - toxins influence on the activated and inactivated receptors; 2 - degree of blocking of KK-activated currents by different studied antagonists; 3 - comparison of degrees of irreversibility of toxins action; 4 -differences in kinetic characteristics of toxins' blocking actions. The relationships between toxins' structures and their electrophysiological characteristics are described; they can be used for the development of novel methods of qualitative and quantitative analysis [27, 33, 37, 38]. For these methods, the patents of Ukraine were obtained [30-38].

\section{ACKNOWLEDGEMENTS}

The author is grateful to people with whom this long-lasting research work became possible: mother - Prof. Dr. Sci. in entomology Z.F. Klyuchko (I.I. Schmalhausen Institute of Zoology, National Academy of Science of Ukraine), and great teachers in neurophysiology - Prof. O.A. Krishtal (O.O. Bogomoletz Institute of Physiology, National Academy of Science of Ukraine) and Prof. N. Akaike (Tokyo University, Japan), as well as to the unforgettable colleagues A.Ya. Tsyndrenko and N.I. Kiskin.

\section{COMPLIANCE WITH ETHICAL STANDARDS}

Conflict of Interest: The authors declare that the research was conducted in the absence of any commercial or financial relationships that could be construed as a potential conflict of interest.

Animal Rights: This article does not contain any studies with animal subjects performed by the any of the authors.

1. Akaike N., Kawai N., Kiskin N.I., Kljuchko E.M., Krishtal O.A., Tsyndrenko A. Ya. Spider toxin blocks excitatory amino acid responses in isolated hippocampal pyramidal neurons. Neurosci. Lett., 1987; 79: 326-330.

[DOI: https://doi.org/10.1016/0304-3940(87)90453-8; Google Scholar]

2. Akhunov A., Chernetsky I.I., Sadykov A.S. Biochemical characteristics of some arthropods venoms of Central Asia. DokI. AN USSR, 1985; 285(4): 1009-1011. (In Russian)

3. Aramaki Y., Yashuhara T., Higashijima T., Yoshioka M., Miwa A., Kawai N., Nakajima T. Chemical characterization of spider toxins JSTX and NSTX. Proc. Japan Academy, 1986; 62(9): 1012-1014.

[DOI: https://doi.org/10.2183/pjab.62.359; Google Scholar]

4. Bateman A., Boden P., Dell A., Duce I.R., Quicke D.L., Usherwood P.N.R. Postsynaptic block of a glutaminergic synapse by low molecular weight fraction of spider venom. Brain Res., 1985; 339(2): 237-244.

[DOI: https://doi.org/10.1016/0006-8993(85)90088-5; Google Scholar]

5. Biner O., Trachsel C., Moser A., Kopp L., Langenegger N., Kämpfer U., von Ballmoos C., Nentwig W., Schürch S., Schaller J., Kuhn-Nentwig L. Isolation, N-glycosylations and function of a hyaluronidase-like enzyme from the venom of the spider Cupiennius salei. PLOS ONE, 2015; 10(12): e0143963.

[DOI: https://doi.org/10.1371/journal.pone.0143963; PMID: 26630650; Google Scholar]

ISSN 1996-4536 (print) • ISSN 2311-0783 (on-line) • Біологічні Студії / Studia Biologica • 2020 • Том 14/№1 • C. 89-104 
6. Budd T., Clinton P., Dell A., Duce I.R., Johnson S.J., Quicke D.L.J., Usherwood P.N.R., Usoh $G$. Isolation and characterisation of glutamate receptor antagonists from venoms of orb-web spiders. Brain Res., 1988; 448(2): 30-39.

[DOI: https://doi.org/10.1016/0006-8993(88)91098-0; Google Scholar]

7. Calvete J.J., Juárez P., Sanz L. Snake venomics. Strategy and applications. J Mass Spectrom., 2007; 42(11):1405-1414.

[DOI: https://doi.org/10.1002/jms.1242; PMID: 17621391; Google Scholar]

8. Casewell N.R., Wüster W., Vonk F.J., Harrison R.A., Fry B.G. Complex cocktails: the evolutionary novelty of venoms. Trends Ecol Evol., 2013; 28(4): 219-229.

[DOI: https://doi.org/10.1016/j.tree.2012.10.020; PMID: 23219381; Google Scholar]

9. Cavigliasso F., Mathé-Hubert H., Kremmer L., Rebuf C., Gatti J.L., Malausa T., Colinet D., Poirié M. Rapid and differential evolution of the venom composition of a parasitoid wasp depending on the host strain. Toxins (Basel), 2019; 11(11): 629.

[DOI: https://doi.org/10.3390/toxins11110629; PMID: 31671900; Google Scholar]

10. Chan Y.S., Cheung R.C.F., Xia L., Wong J.H., Ng T.B., Chan W.Y. Snake venom toxins: toxicity and medicinal applications. Appl Microbiol Biotechnol, 2016; 100(14): 6165-6181.

[DOI: https://doi.org/10.1007/s00253-016-7610-9; PMID: 27245678; Google Scholar]

11. Chemistry and Pharmacology. The Alkaloids. (Ed.) G. A. Cordell, A. Brossi. USA: Academic Press, 1994. 280 p.

12. Daly N.L., Wilson D. Structural diversity of arthropod venom toxins. Toxicon, 2018; 152: 46-56. [DOI: https://doi.org/10.1016/j.toxicon.2018.07.018; PMID: 30040988; Google Scholar]

13. Early S.L., Michaelis E.K. Presence of protein and glutamate as major constituents of the venom of the spider Araneus gemma. Toxicon, 1987; 25(4): 433-442.

[DOI: https://doi.org/10.1016/0041-0101(87)90077-8; Google Scholar]

14. Friedel T., Nentwig $W$. Immobilising and lethal effects of spider venoms on the cockroach and the common meal beetle. Toxicon, 1989; 27(3): 305-316.

[DOI: https://doi.org/10.1016/0041-0101(89)90178-5; Google Scholar]

15. Fortschritte der Chemie organischer Naturstoffe. In: Progress in the Chemistry of Organic Natural Products. (Ed.) W. Herz, G.W. Kirby, R.E. Moore, W. Steglich, Ch. Tamm. USA: Springer Science \& Business Media, 2012; 66: 332 p.

16. Fox J.W., Serrano S.M. Exploring snake venom proteomes: multifaceted analyses for complex toxin mixtures. Proteomics, 2008; 8(4): 909-9020.

[DOI: https://doi.org/10.1002/pmic.200700777; PMID: 18203266; Google Scholar]

17. Georgieva D., Arni R.K., Betzel C. Proteome analysis of snake venom toxins: pharmacological insights. Expert Rev Proteomics, 2008; 5(6): 787-797.

[DOI: https://doi.org/10.1586/14789450.5.6.787; PMID: 19086859; Google Scholar]

18. Ghosh S., Saha K., Dasgupta S.C., Gomes A. In vitro and in vivo anti-arthritic and antiinflammatory activity of bungarus fasciatus venom. J. Toxins, 2015; 2(1): 5-8.

[DOI: https://doi.org/10.13188/2328-1723.1000005; Google Scholar]

19. Grishin E. Spider toxins active on purinergic P2X3 receptor. Toxicon, 2016; 116: 72. [DOI: https://doi.org/10.1016/j.toxicon.2016.01.003; Google Scholar]

20. Grishin E.V., Volkova T.M., Arseniev A.S. Antagonists of glutamate receptors from the venom of Argiope lobata spider. Bioorganicheskaya chimia, 1988; 14(7): 883-892. (In Russian)

21. Grishin E.V., Volkova T.M. Arsenyev A.S., Reshetova O.S., Onoprienko V.V., Magazanik L.G., Antonov S.M., Fedorova I.M. Structural and functional characteristics of argiopin - ion channel blocker from venom of spider Argiope lobata. Bioorganicheskaya chimia, 1986; 12(8): 1121-1124. (In Russian)

22. Hashimoto Y., Endo Y., Shudo K., Aramaki Y., Kawai N., Nakajima T. Synthesis of spider toxin JSTX-3 and its analogs. Tetrah. Lett., 1987; 28(30): 3511-3514.

[DOI: https://doi.org/10.1016/S0040-4039(00)96340-8; Google Scholar]

23. Herzig V. Arthropod assassins: Crawling biochemists with diverse toxin pharmacopeias. Toxicon, 2019; 158: 33-37.

[DOI: https://doi.org/10.1016/j.toxicon.2018.11.312; PMID: 30496730; Google Scholar]

24. Jackson H., Usherwood F. N. R. Spider toxins as tools for dissecting elements of excitatory amino acids transmission. Trends in Neurosci., 1988; 11(6): 278-283.

[DOI: https://doi.org/10.1016/0166-2236(88)90112-9; Google Scholar] 
25. Jankovic J., Albanese A., Atassi M. Z., Dolly J.O., Hallett M., Mayer N.H. Botulinum Toxin E-Book: Therapeutic Clinical Practice and Science. USA: Elsevier Health Sciences, 2009. $512 \mathrm{p}$.

26. Kachel H.S., Buckingham S.D., Sattelle D.B. Insect toxins - selective pharmacological tools and drug/chemical leads. Curr Opin Insect Sci, 2018; 30: 93-98.

[DOI: https://doi.org/10.1016/j.cois.2018.10.001; PMID: 30553492; Google Scholar]

27. Klyuchko O.M., Biletsky A. Ya. Computer recognition of chemical substances based on their electrophysiological characteristics. Biotechnologia Acta, 2019; 12(5): 5-28.

[DOI: https://doi.org/10.15407/biotech12.05.005; Google Scholar]

28. Klyuchko O. M. Chemical substances from terrestrial arthropods as material for laboratory investigations. Biol. Stud., 2019: 13(1); 129-144.

[DOI: https://doi.org/10.30970/sbi.1301.594; Google Scholar]

29. Klyuchko O. M. Active compounds - phenol and indole derivatives of terrestrial arthropods: some electrophysiological and chemical characteristics. Biol. Stud., 2019: 13(2); 99-116. [DOI: https://doi.org/10.30970/sbi.1302.596; Google Scholar]

30. Klyuchko O.M., Biletsky A.Ya., Shutko V.N. Method of production of physical molecular memory in anisotropic media with molecules - derivatives of phenol. Patent UA $135531 \mathrm{U}$; B82Y 40/00, B82Y 10/00, H01B 1/12, C12Q 1/00, G11C 13/00. Priority: 14.12.2018, u201812430, Issued: 10.07.2019, Bull. 13, 10 p. (In Ukrainian)

31. Klyuchko O.M., Biletsky A.Ya., Lizunov G.V., Piankova O.V. Method of application of monitoring system with biosensor and databases. Patent UA $135574 \mathrm{U} ; \mathrm{C} 12 \mathrm{Q} 1 / 02, \mathrm{G} 01 \mathrm{~N} 33 / 00$, G01N33/50, G016F 11/20. Priority: 17.01.2019, u201900475, Issued: 10.07.2019, Bull. 13, 10 p. (In Ukrainian)

32. Klyuchko O.M. Method of application of biotechnical monitoring system for bioindicators' accounting with biosensor and sub-system for optical registration. Patent UA $129987 \mathrm{U}$, G01N33/00, C12Q 1/02, C12N 15/00. Priority: 27.04.2018, u201804662, Issued: 26.11.2018, Bull. 22, 11 p. (In Ukrainian)

33. Klyuchko O.M. Method of qualitative analysis of chemical substances. Patent UA $131016 \mathrm{U}$, G01N33/50, G01N21/78, C12Q 1/60. Priority: 11.05.2018, u201805174, Issued: 10.01.2019,

Bull. 1, 9 p. (In Ukrainian)

34. Klyuchko O.M.. Method for monitoring of chemicals influence on bioorganisms in few time intervals. Patent UA 134575 U; G01N33/00, C12N 15/00, A61P 39/00. Priority: 14.12.2018, u201812443, Issued: 27.05.2019, Bull. 10, 10 p. (In Ukrainian)

35. Klyuchko O.M., Biletsky A. Ya., Navrotskyi D.O. Method of bio-sensor test system application. Patent UA 129923 U, G01N33/00, G01N33/50, C12Q 1/02. Priority: 22.03.2018, u201802896, Issued: 26.11.2018, Bull. 22, 7 p. (In Ukrainian)

36. Klyuchko O. M., Biletsky A. Ya., Navrotskyi D. Method of application of biotechnical monitoring system with expert subsystem and biosensor. Patent UA 131863 U; G01N33/00, C12Q 1/02, C12N 15/00. Priority: 27.04.18, u201804663, Issued: 11.02.2019, Bull. 3, 7 p. (In Ukrainian)

37. Klyuchko O.M., Biletsky A. Ya., Navrotskyi D.A. Method of quantitative analysis of chemical substances. Patent UA 131524 U; G01N33/50, G01N21/78, C12Q 1/60G01N33/50, G01N21/78, C12Q 1/60. Priority: 11.05.2018, u201805175, Issued: 25.01.2019, Bull. 2, 10 p. (In Ukrainian)

38. Klyuchko O.M., Biletsky A.Ya. Method of qualitative analysis of hydrocarbons with harmful and toxic effect on bioobjects. Patent UA 133676 U; G01N 33/50, G01N 21/78. Priority: 06.06.2018, u201806342, Issued: 25.04.2019, Bull. 8, 10 p. (In Ukrainian)

39. Koh D.C., Armugam A., Jeyaseelan K. Snake venom components and their applications in biomedicine. Cell Mol Life Sci, 2006; 63(24): 3030-3041.

[DOI: https://doi.org/10.1007/s00018-006-6315-0; PMID: 17103111; Google Scholar]

40. Kostyuk P.G., Kryshtal O.A. Mechanisms of electrical excitability of the nerve cell. M: Nauka, 1981. 208 p. (In Russian)

41. Kusano Tomonobu, Suzuki Hideyuki. Polyamines: A Universal Molecular Nexus for Growth, Survival, and Specialized Metabolism. USA: Springer, 2015. 336 p.

[DOI: https://doi.org/10.1007/978-4-431-55212-3; Google Scholar] 
42. Lajoie M., Zobel-Thropp B.A., Delahaye B., Roberts S., Kumirov V.K., Bandarian V., Binford G.J., Cordesa M.H.J. The chemistry and functional diversity of spider phospholipase D toxins. Toxicon, 2016; 116: 79.

[DOI: https://doi.org/10.1016/j.toxicon.2016.01.025; Google Scholar]

43. Lee S.Y., Kim S.T., Jung J.K., Lee J.H. A comparison of spider communities in Bt and non-Bt rice fields. Environ Entomol, 2014; 43(3): 819-827.

[DOI: https://doi.org/10.1603/EN12259; PMID: 24874159; Google Scholar]

44. Magazanik L.G., Antonov S.M., Fedorova I.M., Grishin E.V. The action of Argiope lobata spider venom and its low molecular weight component - argiopin on postsynaptic membranes. Biological Membranes, 1986; 3(12): 1204-1219. (In Russian)

45. Magalhães G., Siquueira R., Calabria P., Tavora B., Barbaro K., Faquim-Mauro E., DellaCasa $M$. When spider and snake get along: Fusion of a snake disintegrin with a spider phospholipase D to explore their synergistic effects on a tumor cell. Toxicon, 2019; 1. [DOI: https://doi.org/10.17632/v82sh3rjvc.1; PMID: 31251993; Google Scholar]

46. Magura I.S. Problems of electrical excitability of neuronal membrane. Kyiv: Naukova Dumka, 1981. 208 p. (In Russian)

47. Miwa A., Kawai N., Saito M, Pan-Hou H., Yosioka M. Effect of spider toxin (JSTX) on excitatory postsynaptic current at neuromuscular synapse of spiny lobster. J. Neurophys., 1987; 58(2): 216-220.

[DOI: https://doi.org/10.1152/jn.1987.58.2.319; PMid: 3655870; Google Scholar]

48. Miwa A., Kawai N., Ui M. Pertussis toxin blocks presynaptic glutamate receptor - a novel „glutamate" receptor in lobster neuromuscular synapse. Brain Res., 1987; 416(1): 162-165. [DOI: https://doi.org/10.1016/0006-8993(87)91510-1; Google Scholar]

49. Murúa M.G., Vera M.A., Michel A., Casmuz A.S., Fatoretto J., Gastaminza G. Performance of Field-Collected Spodoptera frugiperda (Lepidoptera: Noctuidae) Strains Exposed to Different Transgenic and Refuge Maize Hybrids in Argentina. Journal of Insect Science, 2019; 19(6): 21.

[DOI: https://doi.org/10.1093/jisesa/iez110; PMID: 31841603; Google Scholar]

50. Pal S.K., Gomes A., Dasgupta S.C., Gomes A. Snake venom as therapeutic agents: from toxin to drug development. Indian J Exp Biol, 2002; 40(12): 1353-8.

51. Pan-Hou H., Suda Y. Molecular action mechanism of spider toxin on glutamate receptor: role of 2,4-dihydroxyphenylacetic acid in toxin molecule. Brain Res., 1987; 418(1): 198-200.

[DOI: https://doi.org/10.1016/0006-8993(87)90981-4; Google Scholar]

52. Pan-Hou H., Suda Y., Sumi M., Yoshioka M., Kawai N. Inhibitory effect of 2,4-dihydroxyphenylacetylasparagine, a common moiety of spider toxins on glutamate binding to rat brain synaptic membranes. Neurosci. Lett., 1987; 81: 199-203.

[DOI: https://doi.org/10.1016/0304-3940(87)90365-X; Google Scholar]

53. Pan-Hou H., Suda Y., Sumi M., Yoshioka M, Kawai N. A spider toxin (JSTX) inhibits L-glutanate uptake by rat brain synaptosomes. Brain Res., 1989; 476(2): 354-357.

[DOI: https://doi.org/10.1016/0006-8993(89)91258-4; Google Scholar]

54. Piek T. Insect venoms and toxins. In: Kerkut G. A. (Ed.) Comprehensive Insect Physiology, Biochemistry and Pharmacology. Oxford: Pergamon Press, 1987; 11: 595-635. [DOI: https://doi.org/10.1016/B978-0-08-030812-8.50019-8]

55. Poulain B., Lemichez E., Popoff M.R. Neuronal selectivity of botulinum neurotoxins. Toxicon, 2020; 178: 20-32.

[DOI: https://doi.org/10.1016/j.toxicon.2020.02.006; PMID: 32094099; Google Scholar]

56. Rádis-Baptista G., Konno K. Arthropod Venom Components and Their Potential Usage. Toxins (Basel), 2020; 12(2): 82.

[DOI: https://doi.org/10.3390/toxins12020082; PMID: 31991714; Google Scholar]

57. Saito M, Kawai N., Miwa A., Pan-Hou H., Yoshioka M. Spider toxin (JSTX) blocks glutamate synapse in hippocampal pyramidal neurons. Brain Res., 1985; 346(2): 397-399.

[DOI: https://doi.org/10.1016/0006-8993(85)90878-9; Google Scholar]

58. Senji Laxme R.R., Suranse V., Sunagar K. Arthropod venoms: Biochemistry, ecology and evolution. Toxicon, 2019; 158: 84-103.

[DOI: https://doi.org/10.1016/j.toxicon.2018.11.433; PMID: 30529476; Google Scholar]

ISSN 1996-4536 (print) • ISSN 2311-0783 (on-line) • Біологічні Студії / Studia Biologica • 2020 • Том 14/№1 • C. 89-104 
59. Scharff N., Coddington J.A., Blackledge T.A., Agnarsson I., Framenau V.W., Szüts T., Cheryl Y., Hayashi C.Y., Dimitrov D. Phylogeny of the orb-weaving spider family Araneidae (Araneae: Araneoidea). Cladistics, 2020; 36(1): 1-21.

[DOI: https://doi.org/10.1111/cla.12382; Google Scholar]

60. Schwartz E.F., Mourão C.B., Moreira K.G., Camargos T.S., Mortari M.R. Arthropod venoms: a vast arsenal of insecticidal neuropeptides. Biopolymers, 2012; 98(4): 385-405. [DOI: https://doi.org/10.1002/bip.22100; PMID: 23193602; Google Scholar]

61. Skock V.I., Selianko A.A., Derckach V.A. Neuronal cholynoreceptors. M: Nauka, 1987. 343 p. (In Russian)

62. Usmanov P.B., Kalikulov D., Shadyeva N.G., Nenilin A.B. Tashmuchamedov B.A. Postsynaptic blocking of glutamatergic and cholinergic synapses as a common property of Araneidae spider venoins. Toxicon, 1985; 23(3): 528-553.

[DOI: https://doi.org/10.1016/0041-0101(85)90038-8; Google Scholar]

63. Vycklicky L., Krusek J., Vycklicky L., Vyskochil F. Spider venom of Araneus opens and desentitizes glutamate channels in chicken spinal cord neurons. Neurosci. Lett., 1986; 68: 227-231. [DOI: https://doi.org/10.1016/0304-3940(86)90147-3; Google Scholar]

64. Walker A.A., Robinson S.D., Yeates D.K., Jin J., Baumann K., Dobson J., Fry B.G., King G.F. Entomo-venomics: The evolution, biology and biochemistry of insect venoms. Toxicon, 2018; 154: 15-27.

[DOI: https://doi.org/10.1016/j.toxicon.2018.09.004; PMID: 30267720; Google Scholar]

65. Walker A.A., Rosenthal M., Undheim E.E.A., King G.F. Harvesting Venom Toxins from Assassin Bugs and Other Heteropteran Insects. J Vis Exp, 2018; (134): e57729.

[DOI: https://doi.org/10.3791/57729; PMID: 29733320; Google Scholar]

\section{ПОРІВНЯЛЬНИЙ АНАЛІЗ ДЕЯКИХ ОТРУТ І ТОКСИНІВ ARANEIDAE: ХІМІЧНІ СТРУКТУРИ Й ЕЛЕКТРОФІЗІОЛОГІЧНІ ВЛАСТИВОСТІ}

О. М. Ключко

Національний авіаційний університет, просп. Любомира Гузара, 1, Київ 03058, Україна e-mail: kelenaXX@nau.edu.ua

Метою публікації був порівняльний аналіз результатів вивчення електрофрізіологічних характеристик токсинів і отрут деяких павуків Araneidae, які мають бути корисними для лабораторної практики та подальших досліджень. Представлено результати досліджень речовин із двох видів павуків - Nephila clavata і Argiope lobata. Вони стали відомими завдяки властивостям їхніх отрут і токсинів як антагоністів глутаматних рецепторів. Ці речовини успішно використовували для дослідження мембранних структур. Результати електрофрізіологічних досліджень отрут і токсинів представлені для отрути з $N$. clavata та його основного діючого компонента токсину JSTX-3, а також для отрути з A. lobata і трьох іï токсинів - аргіопіну AR, аргіопініну 1 (ARN-1), аргіопініну 2 (ARN-2). Представлено дані щодо відповідності між електрофрізіологічними характеристиками дії досліджених токсинів і хімічною структурою їхніх молекул; вони можуть бути застосовані для розвитку новітніх методів якісного та кількісного аналізів. Обговорювалися проблеми комплексного складу отрут, а також можливість повного визначення властивостей отрут за їхніми основними активними компонентами. Розглядалася також роль JSTX-3 як "універсального маркера глутаматергічних синапсів" для різних видів фауни.

Ключові слова: отрути павуків Araneidae, токсини, антагоністи глутаматних рецепторів, трансмембранний електричний струм

Received / Одержано 02 March 2020
Accepted / Прийнято

11 March 2020
Published / Опубліковано 5 May

ISSN 1996-4536 (print) • ISSN 2311-0783 (on-line) • Біологічні Студії / Studia Biologica • 2020 • Том 14/№1 • C. 89-104 